\title{
THE COSTS OF GOING PUBLIC
}

\author{
Jay R. RITTER* \\ Unicersity of Michigan. Ann Arbor, MI $\$ 8109$, USA
}

Received February 1985, final version received January 1987

This paper presents evidence regarding the two quantifiable components of the costs of going public: direct expenses and underpricing. Together, these costs average $21.22^{\circ}$ of the realized market value of the securities issued for firm commitment offers and $31.87 \%$ for best efforts offers. For a given size offer, the direct expenses are of the same order of magnitude for both contract types, but the underpricing is greater for best efforts offers. An explanation of why some firms choose to use best efforts offers in spite of their apparent higher total costs is given.

\section{Introduction}

For firms going public, capital markets are not frictionless. In this paper. I present evidence on the transaction costs of going public. The two cost components that $I$ focus on are the direct costs, which are primarily investment banking fees, and the indirect cost of underpricing. Both components are economically significant, with the total costs, expressed as a percentage of the realized market value of the securities issued, averaging $21.22 \%$ for firm commitment offers and $31.87 \%$ for best efforts offers.

With both types of investment banking contracts, the formal process of going public starts when a registration statement, containing descriptive material about the issuing firm and the proposed offer, is filed with the United States Securities and Exchange Commission (SEC). With a firm commitment offer, the issuing firm and its investment banker then issue a preliminary prospectus and solicit indications of interest from potential investors. Following SEC approval of the offer, the issuing firm and its investment banker hold a pricing meeting at which the offer price and the number of shares to be sold

*Useful comments from E. Han Kim. Saman Majd. Nejat Seyhun, an anonymous referee. and Clifford Smith and Michael Jensen (the editors), are gratefully acknowledged. Special thanks are owed to Harry DeAngelo. whose extensive comments have substantially improved the substance and exposition of this paper. An earlier version of this paper, entitled 'The Choice Between Firm Commitment and Best Efforts Contracts' was presented at the Ohio State University, Stanford University. University of Michigan. University of Minnesota. University of Pennsylvania, and the University of Rochester MERC Conference on Investment Banking and the Capital Acquisition Process in April 1985. This research was partially funded by a summer research fund grant from the University of Michigan Business School. 
are agreed upon (with the investment banker usually being granted an overallotment option to sell as many as $15 \%$ more shares). Only when the final prospectus is issued does the investment banker guarantee to deliver the proceeds (net of commissions) to the issuing firm, whether or not the offer is fully subscribed at the offer price. Once an offer price has been set, shares cannot be sold at a higher price even if demand for the issue is unexpectedly strong, although the investment banker is permitted to sell shares at a lower price if it breaks the syndicate.

With a best efforts contract, the issuing firm and its investment banker agree on an offer price and a minimum and maximum number of shares to be sold. Following SEC approval, the investment banker then circulates a prospectus and makes its 'best efforts' to sell the shares to investors. During this selling period. interested investors indicate interest by depositing money in an escrow account established by the underwriter. If the minimum number of shares is not sold at the offer price within a specified period of time, usually 90 days, the offer is withdrawn, and the investors' money is refunded, with the issuing firm receiving no money.

Although the costs of going public are on average much higher for best efforts offers, this is partly because there are substantial economies of scale, and best efforts offers tend to be smaller than firm commitment offers. If issue size is held constant, however, best efforts offers still seem to be somewhat more costly. This raises the question of why many firms $(35.4 \%$ of the total in the 1977-1982 period) choose to use best efforts contracts, in spite of their apparent cost disadvantage. I analyze this contract choice decision, focusing on the role of asymmetric information among investors. I discuss the circumstances under which each of the two strategies, firm commitment and best efforts contracts, is optimal for the issuing firm.

The organization of this paper is as follows. In section 2, descriptive statistics for firm commitment and best efforts offers are presented. In section 3, I analyze Mandelker and Raviv's (1977) optimal risk-sharing argument for the contract choice decision. In section 4, I give an explanation for the choice between the two contract types based on asymmetric information among investors. Section 5 presents empirical evidence supporting that explanation, and the paper ends with a brief summary and discussion.

\section{The characteristics of firm commitment and best efforts offers}

Table 1 reports descriptive statistics for the 1,028 firms that were taken public by investment bankers in the United States in 1977-1982. ${ }^{1}$ The data are

\footnotetext{
'The data exclude Regulation $A$ offers, for which firms raising less than $\$ 1.5$ million are eligible. The disclosure requirements for Regulation A offers are substantially less than for the S-1, S-2. and S- 18 offers that comprise the sample used here.
} 
Table 1

Average gross proceeds, sales, and book values for firms going public in 1977-1982. categorized by contract type.

\begin{tabular}{|c|c|c|c|}
\hline & $\begin{array}{l}\text { All } \\
\text { offers }\end{array}$ & $\begin{array}{c}\text { Firm } \\
\text { commitment } \\
\text { offers }^{3}\end{array}$ & $\begin{array}{l}\text { Best } \\
\text { efforts } \\
\text { offers }\end{array}$ \\
\hline Average gross proceeds ${ }^{b . c}$ & $\begin{array}{l}\$ 6.575 .616 \\
(9,788,007)^{\mathrm{f}}\end{array}$ & $\begin{array}{l}\$ 8 . \$ 80.906 \\
(11.437,137)\end{array}$ & $\begin{array}{l}\$ 2,370.362 \\
(2,164,255)\end{array}$ \\
\hline $\begin{array}{l}\text { Average annual sales in } \\
\text { year prior to offer }\end{array}$ & $\begin{array}{l}\$ 13.144 .048 \\
(45.383 .358)\end{array}$ & $\begin{array}{l}\$ 20.048 .473 \\
(55.252 .680)\end{array}$ & $\begin{array}{c}\$ 549.162 \\
(2,238.552)\end{array}$ \\
\hline $\begin{array}{l}\text { Average pre-offer } \\
\text { book value of equity }\end{array}$ & $\begin{array}{l}\$ 2,928.067 \\
(7,155,382)\end{array}$ & $\begin{array}{l}\$ 4.365 .539 \\
(8.557 .460)\end{array}$ & $\begin{array}{l}\$ 305.865 \\
(654.336)\end{array}$ \\
\hline $\begin{array}{l}\text { Number of firms } \\
\text { (percent of total) }\end{array}$ & $\begin{array}{c}1,028 \\
(100.0 \%)\end{array}$ & $\begin{array}{c}664 \\
(64.6 \%)\end{array}$ & $\begin{array}{r}364 \\
(35.4 \%)\end{array}$ \\
\hline $\begin{array}{l}\text { Gross proceeds as a } \\
\text { percent of total }\end{array}$ & $100.0^{\circ}:$ & $87.2 \%$ & $12.8^{\circ}$ \\
\hline
\end{tabular}

${ }^{2}$ Four combined firm commitment-best efforts offers are classified as firm commitment offers.

${ }^{b}$ All of the averages (gross proceeds, sales, book value) are averages of nominal values; no price level adjustments have been made.

"Gross proceeds are total dollars raised: the offer price times the number of shares sold.

'Sales are the most recent twelve-month revenues reported in the firm's offer prospectus.

'Book value is for the most recent date reported in the firm's offer prospectus.

${ }^{\mathrm{f}}$ For the top three categories, the figures in parentheses are the standard deviations.

described in more detail in Ritter (1984) and Beatty and Ritter (1986). Table 1 shows that the average firm commitment offer raises almost four times as much money as the average best efforts offer ( $\$ 8.88$ million vs. $\$ 2.37$ million). Further, firm commitment offers are used by firms that are. on average, substantially larger in sales and book value. Table 1 also shows that while firm commitment contracts are used in $64.6 \%$ of all offers, they account for $87.2 \%$ of the proceeds.

In table 2 I categorize offers by gross proceeds and contract type. As the table shows, $72.0 \%$ of the offers that raise less than $\$ 2$ million use a best efforts contract, whereas only $2.8 \%$ of the offers that raise $\$ 10$ million or more use this contract. ${ }^{2}$

In table 3, I report the direct costs of going public. These include underwriter commissions; legal, printing, and auditing expenses; and other out-ofpocket costs. The existence of substantial economies of scale is evident. The table 3 evidence indicates that the direct costs of going public are equal to

2Other differences between the two contract types include the 'quality' of the underwriters employed. Only one of the 364 best efforts offers in 1977-1982 was conducted by a 'major bracket' investment banker. Most underwriters restrict themselves to either best efforts or firm commitment offers. Another differenee is that firm commitment offers are bought primarily by institutional investors, whereas best efforts offers are purchased almost exclusively by individual investors. 
Table 2

1977-1982 initial public offers categorized by gross proceeds and contract type.

\begin{tabular}{ccccc}
\hline Gross proceeds $(\$)^{\text {a }}$ & $\begin{array}{c}\text { All } \\
\text { offers }\end{array}$ & $\begin{array}{c}\text { Firm } \\
\text { commitment } \\
\text { offers }\end{array}$ & $\begin{array}{c}\text { Best } \\
\text { efforts } \\
\text { offers }\end{array}$ & $\begin{array}{c}\text { Fraction } \\
\text { best efforts } \\
\text { offers }\end{array}$ \\
\hline $100.000-1.999,999$ & 243 & 68 & 175 & 0.720 \\
$2.000 .000-3,999.999$ & 311 & 165 & 146 & 0.469 \\
$4.000 .000-5.999 .999$ & 156 & 133 & 23 & 0.147 \\
$6.000 .000-9.999 .999$ & 137 & 122 & 15 & 0.109 \\
$10.000 .000-120.174 .195$ & 181 & 176 & 5 & 0.028 \\
All offers & 1028 & 664 & 364 & 0.354 \\
\hline
\end{tabular}

${ }^{a}$ The gross proceeds categories are based on the nominal values; no price level adjustments have been made.

Table 3

Direct expenses of going public as a percentage of gross proceeds. 1977-1982.

\begin{tabular}{|c|c|c|c|c|}
\hline Gross proceeds $(\$)^{a}$ & $\begin{array}{c}\text { Number of } \\
\text { offers }\end{array}$ & $\begin{array}{l}\text { Underwriting } \\
\text { discount }(\mathscr{C})^{b}\end{array}$ & $\begin{array}{c}\text { Other } \\
\text { expenses }(\%)^{\circ}\end{array}$ & $\begin{array}{c}\text { Total cash } \\
\text { expenses (\%) }\end{array}$ \\
\hline \multicolumn{5}{|c|}{ Firm commitment offers } \\
\hline $100,000-1,999.999$ & 68 & 9.84 & 9.64 & 19.48 \\
\hline $2.000 .000-3,999,999$ & 165 & 9.83 & 7.60 & 17.43 \\
\hline $4,000,000-5,999,999$ & 133 & 9.10 & 5.67 & 14.77 \\
\hline $6,000,000-9,999,999$ & 122 & 8.03 & 4.31 & 12.34 \\
\hline $10.000 .000-120,174,195$ & 176 & 7.24 & 2.10 & 9.34 \\
\hline All offers & 664 & 8.67 & 5.36 & 14.03 \\
\hline \multicolumn{5}{|c|}{ Best efforts offers } \\
\hline $100,000-1,999.999$ & 175 & 10.63 & 9.52 & 20.15 \\
\hline $2.000,000-3.999,999$ & 146 & 10.00 & 6.21 & 16.21 \\
\hline $4.000 .000-5.999 .999$ & 23 & 9.86 & 3.71 & 13.57 \\
\hline $6,000,000-9.999 .999$ & 15 & 9.80 & 3.42 & 13.22 \\
\hline $10.000,000-120,174,195$ & 5 & 8.03 & 2.40 & 10.43 \\
\hline All offers & 364 & 10.26 & 7.48 & 17.74 \\
\hline
\end{tabular}

${ }^{a}$ Gross proceeds categories are nominal; no price level adjustments have been made.

'The underwriting discount is the commission paid by the issuing firm; this is listed on the front page of the firm's prospectus.

"The other expenses figure comprises accountable and non-accountable fees of the underwriters, cash expenses of the issuing firm for legal, printing, and auditing fees. and other out-of-pocket costs. These other expenses are described in footnotes on the front page of the issuing firm's prospectus. None of the expense categories include the value of warrants granted to the underwriter, a practice that is common with best efforts offers. 
Table 4

Average percentage cash expenses and initial returns. and total transaction costs as a percentage of realized market values, $1977-1982$.

\begin{tabular}{|c|c|c|c|c|}
\hline Gross proceeds $(\$)^{d}$ & $\begin{array}{c}\text { Number of } \\
\text { offers }\end{array}$ & $\begin{array}{c}\text { Cash } \\
\text { expenses }(c \cdot c)^{\mathrm{b}}\end{array}$ & $\begin{array}{l}\text { Avg. initial } \\
\text { returns }(g,)^{\circ}\end{array}$ & $\begin{array}{l}\text { Avg. total } \\
\text { costs }(q)^{d}\end{array}$ \\
\hline \multicolumn{5}{|c|}{ Firm commitment offers } \\
\hline $\begin{array}{c}100.000-1.999 .999 \\
2.000 .000-3.999 .999 \\
4.000 .000-5.999 .999 \\
6.000 .000-9.999 .999 \\
10.000 .000-120.174 .195\end{array}$ & $\begin{array}{r}68 \\
165 \\
133 \\
122 \\
176\end{array}$ & $\begin{array}{r}19.48 \\
17.43 \\
14.77 \\
12.34 \\
9.34\end{array}$ & $\begin{array}{r}26.92 \\
20.70 \\
12.57 \\
8.99 \\
10.32\end{array}$ & $\begin{array}{l}31.73 \\
24.93 \\
20.90 \\
17.85 \\
16.27\end{array}$ \\
\hline All offers & 664 & 14.03 & 14.80 & 21.22 \\
\hline \multicolumn{5}{|c|}{ Best efforts offers } \\
\hline $\begin{array}{c}100.000-1.999 .999 \\
2.000 .000-3.999 .999 \\
4.000 .000-5.999 .999 \\
6.000 .000-9.999 .999 \\
10.000 .000-120.174 .195\end{array}$ & $\begin{array}{r}175 \\
146 \\
23 \\
15 \\
5\end{array}$ & $\begin{array}{l}20.15 \\
16.21 \\
13.57 \\
13.22 \\
10.43\end{array}$ & $\begin{array}{r}39.62 \\
63.41 \\
26.82 \\
40.79 \\
-5.42\end{array}$ & $\begin{array}{c}31.89 \\
36.28 \\
14.49 \\
25.97 \\
-0.17^{c}\end{array}$ \\
\hline All offers & 364 & 17.74 & 47.78 & 31.87 \\
\hline
\end{tabular}

${ }^{3}$ Gross proceeds categories are nominal: no price level adjustments have been made.

${ }^{h}$ The cash expenses are those reported in table 3.

'The initial returns are computed as $(v-O P) \div O P$. multiplied by $100^{\circ}$, where $t$ is the closing bid price on the first day of trading and $O P$ is the offer price. These are not annualized returns.

$\checkmark$ Total costs are computed as $100 \%$ minus the net proceeds as a percentage of the market value of securities in the aftermarket. Consequently, total costs are not the simple sum of cash expenses and the average initial return.

"For best efforts offers of $\$ 10$ million or more, the negative average total costs are due to the price declines suffered by several offers. For three of the five firms in this category, net proceeds exceeded the post-offer market value of the securities issued.

approximately $\$ 250,000$ plus $7 \%$ of the gross proceeds. For an offer of a given size, the direct costs are of the same order of magnitude for both firm commitment and best efforts offers, although the costs for best efforts contracts are understated because the value of warrants, which are commonly granted to the underwriter, is excluded. Nevertheless, these costs are substantially higher than those that Smith (1977) reports for seasoned equity issues.

The direct cost of going public is only one component of the total costs. A second cost is the underpricing cost. ${ }^{3}$ (This is known as the money 'left on the table'.) For initial public offers, this is substantial, as reported in table 4. The average initial return, defined as the percentage price change from the offer price to the first day's closing bid price, is $14.80 \%$ for firm commitment offers and $47.78 \%$ for best efforts offers. Further, best efforts offers have higher

\footnotetext{
${ }^{3}$ There is another component not dealt with in this paper: management time and effort. No data exist on the monetary equivalent of this cost.
} 
average initial returns than firm commitment offers in all but the largest of the five gross proceeds categories. (In the largest gross proceeds category, there are only five best efforts offers.) Thus, while the direct costs of going public are comparable for firm commitment and best efforts offers, holding the offer size constant, the indirect cost of underpricing is greater for best efforts offers. Consequently, the toral costs of going public are higher for best efforts offers. as shown in the average total costs columns in table 4.

If best efforts offers are more expensive than firm commitment offers, why do over one-third of offers use best efforts contracts?

\section{Optimal risk-sharing as an explanation of the contract choice decision}

One potential reason for choosing between a firm commitment and a best efforts contract, given by Mandelker and Raviv (1977), concerns the optimal bearing of proceeds risk, defined as the uncertainty about the amount of money being raised. Mandelker and Raviv argue that in a best efforts offer the issuing firm bears the proceeds risk, whereas in a firm commitment offer the investment banker bears this risk.

For firm commitment offers, a preliminary prospectus is typically issued several weeks before the actual offer. The preliminary prospectus shows tentative minimum and maximum offer prices and a tentative number of shares to be sold. The actual minimum and maximum number of shares and the offer price are determined only at the pricing meeting, which usually occurs the day before the offer; ${ }^{4}$ the offer price and number of shares can be. and frequently are, substantially different from those shown in the preliminary prospectus.

In table 5, I present data on just how large these changes are, using offers for 1982. only, including best efforts offers that were withdrawn. ${ }^{5}$ In row 1.1 have computed the 'expected' gross proceeds of $\$ 10,159,670$ for firm commitment offers by finding the weights for the minimum and maximum amounts from the preliminary prospectus so that the 'expected' gross proceeds equals. on average, the realized gross proceeds. The last column shows that the average absolute percentage change between the actual realized gross proceeds and the expected gross proceeds was $23.8 \%$ for firm commitment offers. In

\footnotetext{
${ }^{4}$ Most firm commitment offerings give the underwriter an option to increase the number of shares above the guaranteed minimum if demand is strong. During the 1977-1982 period. $85.2 \mathrm{E}$ of the 664 firm commitment offers had an overallotment option allowing the investment banker to increase the size of the offer by as much as $10 \%$. In 1983, the SEC began permitting firm commitment offers to include an overallotment option of up to $15 \%$. The underwriters normally have 30 days after the offering in which to exercise the overallotment option. although it is usually exercised immediately.

${ }^{5}$ I analyze only the offers in 1982, rather than 1977-1982, as in the rest of the tables. because of the extensive time required to track down and transcribe data from the preliminary prospectuses of firm commitment offers and from withdrawn best efforts offers.
} 
Table 5

Mean 'expected' and actual gross proceecs $2^{\prime \prime}$ werage absolute percentage deviation from 'expected' amounts. by contract type for initial public offers in 1982.

\begin{tabular}{|c|c|c|c|}
\hline Category & $\begin{array}{l}\text { Average 'expected' } \\
\text { gross proceeds }\end{array}$ & $\begin{array}{l}\text { Average actual } \\
\text { gross proceeds }\end{array}$ & $\begin{array}{l}\text { Average absolute } \\
\text { percentage deviation } \\
\text { from 'expected" } \\
\text { gross proceeds }\end{array}$ \\
\hline 116 Firm commitment & $\$ 10.159 .670^{4}$ & $\$ 10.159 .670$ & $23.8 \mathrm{c}^{\mathrm{b}}$ \\
\hline $\begin{array}{l}82 \text { Successful best } \\
\text { efforts offers } \\
73 \text { Unsuccessful best }\end{array}$ & $\$ 1,908,504^{\circ}$ & $\$ 1.908 .504$ & $18.2^{\circ} \mathrm{C}$ \\
\hline $\begin{array}{l}\text { efforts offers } \\
155 \text { Attempted best }\end{array}$ & $\$ 2,600,178^{\circ}$ & 0 & $100.0 \%$ \\
\hline efforts offers & $\$ 2.234 .260$ & $\$ 1.009 .660$ & $56.7^{\circ}$ \\
\hline
\end{tabular}

"For firm commitment offers, the 'expected' gross proceeds is computed as 0.663 of the minimum and 0.337 of the maximum proposed gross proceeds in the preliminary prospectus. These are the weights for the 106 firm commitment offers for which there was complete information that make the 'expected' proceeds equal to the average realized proceeds. In the preliminary prospectus, an offer price range is usually specified, along with a proposed number of shares. The minimum proposed gross proceeds is the minimum offer price multiplied by the number of shares. The maximum proposed gross proceeds is the maximum offer price multiplied by the maximum number of shares. assuming that any overallotment option is exercised.

'Information on the preliminary offer price range is incomplete for 10 of the 116 firm commitment ofiers in 1982. Consequently, the average absolute percentage deviation is based on only 106 offers.

"For best efforts offers. the 'expected' gross proceeds is computed as 0.653 of the minimum and 0.347 of the maximum number of shares offered times the offer price. These are the weights for the 82 successful offers that make the 'expected' proceeds equal to the average realized proceeds.

${ }^{4}$ The 73 withdrawn best efforts offers are those best efforts offers that had effective dates between October 1981 and September 1982 and were later withdrawn. Best efforts offers that are withdrawn are usually withdrawn 3 months after the effective date; reliable data on the exact dates the 73 offers were withdrawn are unavailable.

"Of the 73 withdrawn best efforts offers. data on the minimum number of shares offered are unavailable for 10 . Most of the 10 had registered as firm commitment offers and later switched to best efforts offers before being withdrawn. Consequently, the 'expected' gross proceeds is based on only 63 failed offers.

other words, for a firm that in the preliminary prospectus indicates it will sell 1 million shares at $\$ 9.00-\$ 11.00$ a share, it is not at all unusual to have the offer scaled back to, say, 800,000 shares at $\$ 8.00$ or increased to 1.2 million shares at $\$ 12.00$. (The number of shares and the offer price are almost always changed in the same direction.) Thus, only a few weeks before the offer, the issuing firm has substantial uncertainty about how much money will be raised. ${ }^{\circ}$

These revisions are why the investment banker's guarantee of the proceeds is so misleading: the guarantee isn't made until the final pricing meeting, when

\footnotetext{
${ }^{6}$ For an account of the process of going public for one company, see Uttal (1986)
} 
the investment banker has a good (although not perfect) idea of how much money can be raised. ${ }^{7}$ Consequently, it is rare for investment bankers to sell fewer than the guaranteed minimum number of shares at the offer price. Practitioners have told me that, at most, only $10 \%$ of firm commitment offers are not fully subscribed, and even when they aren't, usually only a small fraction of the shares must be sold at a lower price, and it usually isn't too much lower. As a practical matter, the investment banker in a firm commitment offer bears little risk; essentially all of the proceeds risk is borne by the issuing firm.

The remaining three rows of table 5 contain figures for best efforts offers, including 73 failed offers. I have computed the 'expected' gross proceeds in a manner analogous to that for firm commitment offers. (1982 was somewhat unusual, in that an unusually large fraction of best efforts offers failed.) Largely because so many offers fail, there is substantial proceeds risk for firms attempting to go public using a best efforts contract. ${ }^{8}$

In summary, table 5 shows that the issuing firm bears substantial proceeds risk for both firm commitment and best efforts offers, although it is higher for best efforts offers. Finally, it should be noted that the average absolute deviations reported in table 5 are lower bounds to the actual proceeds risk. This is because many offers (both best efforts and firm commitment) are withdrawn before a prospectus is issued.

\section{An explanation based on asymmetric information among investors}

An implication of Rock's (1986) model of the underpricing of initial public offers, developed in Beatty and Ritter (1986), is that firm commitment offers will be underpriced more (in an expected value sense) the greater is the ex ante uncertainty about an issuing firm's value. This occurs because, if potential investors have differential information, informed investors impose an adverse selection cost on uniformed investors. Since informed investors submit more purchase orders for underpriced offers than for overpriced offers, uniformed investors wind up being allocated a disproportionately small fraction of underpriced offers and a disproportionately large fraction of overpriced offers. Consequently, uninformed investors find themselves facing a situation in which their expected return conditional on receiving shares is lower than their

'As Smith (1986a. p. 23) notes, the investment banker's guarantee can be viewed as the granting of a put option to the issuing firm. I am arguing that the exercise price of this option is set in a manner that makes the value of this put option nearly worthless. Smith $(1977$, p. 289) makes a similar point about the value of this put option for a new issue by a publicly-traded firm.

"Typically, firms whose offers are withdrawn don't try again. I have found very few instances of a best efforts offer being withdrawn in which the firm subsequently went public. If alternative sources of financing are not found by these firms, then the net present value of foregone investments is an additional cost borne by firms that attempt to raise capital with best efforts contracts and withdraw the offer. 
expected return conditional on submitting a purchase order. The difference between these two conditional expected returns becomes larger as the dispersion of possible firm values increases. Thus, uniformed investors will be willing to submit purchase orders for more speculative initial public offers only if the expected underpricing is greater than for issues for which there is less ex ante uncertainty about true firm value.

With a best efforts offer, if the offer is not fully subscribed, it is withdrawn. Thus, the adverse selection problem that uniformed investors face with a firm commitment offer is ameliorated. Because uniformed investors do not face a severe adverse selection problem for which they have to be compensated, an issuing firm does not have to severely underprice its shares, as it would with a firm commitment offer. A best efforts offer is not without a disadvantage for the issuing firm, however - if the offer is withdrawn, the issuer receives no funds. This risk is worth taking only if the reduction in the degree of underpricing is sufficiently great.

With a best efforts contract, the issuing firm finds it optimal to set a threshold level of demand high enough that uniformed demand is insufficient to fill it. By doing so, the issuer induces uniformed investors to submit purchase orders (with their money placed in an escrow account) for a best efforts offer with a high offer price, when they would be unwilling to do so for a firm commitment offer. Because the issuer precommits to withdraw offers for which informed demand is not forthcoming, the issuer can set a higher offer price, involving less dilution, than it could with a firm commitment offer.

Using the above reasoning, Ritter (1987) formally demonstrates that firms whose value is more certain will use firm commitment offers, and firms whose value is highly uncertain will use best efforts offers.

\section{Empirical evidence}

To test the section 4 prediction relating ex ante uncertainty to the contract choice, a proxy for ex ante uncertainty is needed. One observable variable that is plausibly related to ex ante uncertainty is the daily standard deviation of returns in the aftermarket. It seems likely that firms with volatile stock prices are firms whose market value was highly uncertain before public trading began. To calculate the daily standard deviation of returns, I use the first 20 daily closing bid prices in the aftermarket. 9 These bid prices are publicly available for NASDAQ-listed new issues in Standard and Poor's Daily Stock Price Record for Over-the-Counter Stocks. For approximately $10 \%$ (primarily small offers) of the population of firms mounting initial public offers in the 1977-1982 period, the Daily Stock Price Record does not have daily price

\footnotetext{
${ }^{9}$ The NASDAQ National Market Issues listings, where only a closing transaction price is reported, rather than the closing bid price, did not begin until 1983.
} 
Table 6

Fraction of NASDAQ-listed offers in 1977-1982 using best efforts contracts categorized by gross proceeds and aftermarket standard deviation.

\begin{tabular}{cccc}
\hline Gross proceeds $(\$)^{\mathrm{h}}$ & \multicolumn{2}{c}{ Aftermarket daily standard deviation } & $\begin{array}{c}F \text {-statistice } \\
(p \text {-value })\end{array}$ \\
\cline { 2 - 4 } $100.000-1.999 .999$ & Below median & At or above median & 16.23 \\
$2.000 .000-3.999 .999$ & 0.436 & 0.743 & $(0.0001)$ \\
& $(n=55)$ & $(n=109)$ & 21.37 \\
$4.000 .000-5.999 .999$ & 0.275 & $(n=203)$ & $(0.0001)$ \\
& 0.026 & 0.273 & 20.36 \\
$6.000 .000-9.999 .999$ & $(n=76)$ & $(n=77)$ & $(0.0001)$ \\
& 0.022 & 0.273 & 23.52 \\
$10.000 .000-120.174 .195$ & $(n=92)$ & $(n=44)$ & $(0.0001)$ \\
& 0.021 & 0.054 & 1.17 \\
& $(n=142)$ & $(n=37)$ & $(0.2816)$ \\
\hline
\end{tabular}

${ }^{a}$ Only the 926 NASDAQ-listed offers are used because daily price data are not readily available for non-NASDAQ-listed OTC stocks. Of the 926 offers. 641 used firm commitment contracts and 285 used best efforts contracts. Only $67.5 \%$ of offers under $\$ 2$ million were subsequently listed on NASDAQ . compared with $97.1 \%$ of offers of $\$ 2$ million or more.

"The proceeds categories are based on the nominal values; no price level adjustments have been made. The corresponding table in real terms (not reported here) shows a qualitatively similar pattern, but the quantitative differences are even stronger than those shown above.

"The median daily aftermarket standard deviation is $4.3 \%$.

$\checkmark$ The average aftermarket daily standard deviation is $4.2 \%$ for tirm commitment offers and $7.6 \%$ for best efforts offers.

"The $F$-statistics test the hypothesis that the mean fraction using best efforts contracts is the same for both high and low aftermarket standard deviation firms. The $p$-value is the probability that the $F$-statistic would be as large or larger under the null hypothesis that the fraction of offers using best efforts contracts is unrelated to the aftermarket daily standard deviation category, assuming independence of each offer.

quotations beginning when the stock started trading in the aftermarket. Since no other source of daily quotations is readily available for these firms, only 926 of the total sample of 1,028 firms have been used.

One potential problem in using the aftermarket standard deviation of returns as a proxy for ex ante uncertainty is that this variable is correlated with firm size, as measured by the gross proceeds. The simple correlation coefficient between the aftermarket standard deviation and the log of gross proceeds is -0.31 . To control for possible confounding effects, in table $6 \mathrm{I}$ report the fraction of offers using best efforts contracts using the same gross proceeds categories as in tables 2,3 , and 4 . For each gross proceeds category, I report the fraction of offers using a best efforts contract for firms with low and high aftermarket standard deviations, where the cutoff for these two categories is the sample median value of $4.3 \%$ per day. 
For all five gross proceeds categories in table 6 the fraction of offers using best efforts contracts is higher for firms in the high aftermarket standard deviation category than for those with low aftermarket standard deviations. The differences are striking: for both the $\$ 4,000,000-\$ 5,999,999$ and $\$ 6.000,000-\$ 9,999,999$ categories, the fraction of offers using best efforts contracts is more than ten times larger in the high aftermarket standard deviation category.

An $F$-test of the hypothesis that the fraction of firms using best efforts contracts is the same for both low and high aftermarket standard deviation categories leads to rejection of the null hypothesis at high levels of statistical significance for all but the largest gross proceeds category. (In the largest gross proceeds category, the small number of best efforts offers makes it difficult to reject any hypothesis at conventional levels of statistical significance.) The results reported in table 6 strongly support the proposition that firms with higher ex ante uncertainty are more likely to use a best efforts contract than a firm commitment contract.

Further evidence supporting the notion that only firms whose value is highly uncertain will use a best efforts contract is contained in Booth and Smith (1986). Since the ex ante uncertainty about the market price of a stock that is currently traded is minimal compared with the uncertainty in most initial public offerings, I would predict that few seasoned equity offers use a best efforts contract. Using the SEC's Registration and Offer Statistics (ROS) data set for 1977-1982, Booth and Smith report in their table 1 that $54.3 \%$ of initial public offers of common stock used a best efforts contract, whereas only $2.6 \%$ of seasoned equity offers used such a contract. ${ }^{10}$

I have argued that uniformed investors face less adverse selection risk with best efforts offers than with firm commitment offers, because overpriced best efforts offers are withdrawn. A literal interpretation of this statement would predict that no best efforts offers experience negative initial returns. In practice, some do have negative initial returns, possibly because of new negative information that arrives toward the end of the selling period. Still, if best efforts offers do result in less adverse selection risk for uninformed investors. I would expect to see a smaller proportion of best efforts offers than firm commitment offers experiencing negative initial returns. In fact, among the 1,028 initial public offers in $1977-1982,24.7 \%$ of firm commitment offers had negative initial returns, whereas only $16.5 \%$ of completed best efforts

\footnotetext{
16) Booth and Smith (1986, table 1) report that 54.3\% of initial public offers in 1977-1982 used best efforts contracts. whereas table 1 of this paper reports only $35.4 \%$ as using a best efforts contract. Booth and Smith's data source (the ROS data set) lists only 396 of the 664 firm commitment offers that I have, whereas it lists 470 best efforts offers, as compared to only 364 in my data set. In direct inspection of all 1,028 prospectuses in my data set, I found no misclassifications of the contract type. In an inspection of the ROS data set. I found numerous misclassifications of the contract type, as well as misclassifications of new issues in terms of whether the issue was a seasoned or unseasoned (initial public) offer.
} 
offers had negative initial returns. This is further indirect evidence consistent with the notion that issuing firms are motivated by considerations relating to informational asymmetries among investors in choosing the contract form.

\section{Conclusions}

This paper documents the differences in the types of firms using firm commitment and best efforts contracts. These differences are striking: small, more speculative firms tend to raise small amounts of money using best efforts offers, and larger, more established firms tend to raise large amounts of money using firm commitment contracts. With either type of contract, the average transaction costs are noteworthy: $21.22 \%$ for firm commitment offers and $31.87 \%$ for best efforts offers. Although part of the lower average cost for firm commitment offers is due to the existence of substantial economies of scale, it appears that for an offer of a given size, the total transaction costs for a best efforts contract are higher than for a firm commitment contract. Further, the proceeds risk borne by the issuing firm, although substantial with both contract types, appears to be much greater for best efforts contracts. Yet many firms still choose to use best efforts contracts. I resolve this apparent paradox as follows: if there is enough uncertainty about the value of the firm, an issuing firm is better off using a best efforts contract because the required underpricing if it used a firm commitment contract would be so severe. Using a data set of initial public offers from 1977-1982, I find empirical results consistent with the theory: firms that are more volatile in the aftermarket are more likely to have used a best efforts contract to go public.

Analyzing the contract choice decision in terms of the effect on the adverse selection problem facing investors sheds light on the existence of overallotment options in firm commitment offers. As mentioned earlier, most firm commitment offers include a feature in which the underwriter has the option of selling as many as $15 \%$ more shares than the guaranteed number. The underwriter's ability to exercise this option for oversubscribed (i.e., underpriced) offers helps to ameliorate the adverse selection problem facing uninformed investors. Consequently, an overallotment option may reduce the degree of underpricing required in a firm commitment offer.

An alternative (although not mutually exclusive) rationale for the existence of overallotment options is suggested by Smith (1986b, p. 20). Since the profit margin on the commissions an investment banker receives on incremental shares sold through the overallotment option is very high, investment bankers have an incentive to underprice an offer that includes an overallotment option in order to increase the probability of exercising the option. Because of this incentive structure, investors can rationally interpret the existence of an overallotment option on an offer as indicating a low probability that it will be overpriced. 
When an investment banker takes a firm public. the underwriter is both certifying and distributing the issue. As discussed in the introduction. in a best efforts offer the offer price is set earlier in the process of going public than in a firm commitment offer. With a firm commitment offer, the investment banker gathers more information (and, as a byproduct, redistributes it) about market demand before setting the offer price than is done with a best efforts contract. Thus, a firm commitment offer involves relatively more certification than a best efforts offer. This is consistent with the fact that the 'major bracket' investment bankers almost always do firm commitment offers.

\section{References}

Beatty. Randolph and Jay Ritter. 1986. Investment banking. reputation, and the underpricing of initial public offerings. Journal of Financial Economics 15, 213-232.

Booth. James R. and Richard L. Smith, 1986, Capital raising, underwriting and the certitication hypothesis. Journal of Financial Economics 15, 261-281.

Mandelker. Gershon and Artur Raviv, 1977. Investment banking: An economic analysis of optimal underwriting contracts, Journal of Finance 32, 683-694.

Ritter, Jay R.. 1984. The 'hot issue' market of 1980 . Journal of Business 32, 215-240.

Ritter. Jay R., 1987. A theory of investment banking contract choice, Unpublished working paper (University of Michigan, Ann Arbor, MI).

Rock. Kevin F., 1986, Why new issues are underpticed, Journal of Financial Economics 15. $187-212$

Smith. Clifford W.. Jr., 1977. Alternative methods for raising capital: Rights versus underwritten ofiers. Journal of Financial Economics 5, 273-307.

Smith. Clifford W., Jr. 1986a, Investment banking and the capital acquisition process, Journal of Financial Economics 15. 3-30.

Smith. Clifford W.. Jr., 1986b, Raising capital: Theory and evidence, Midland Corporate Finance Journal 4. 6-22.

Standard and Poor's. 1977-82. Daily stock price record for over-the-counter stocks (Standard and Poor's Corporation. New York).

Uttal, Bro, 1986, Inside the deal that made Bill Gates $\$ 350,000,000$, Fortune 114, July 21, 23-33. 